\title{
Photodegradation of Sugarcane Bagasse Fibers. Influence of Acetylation or Grafting UV-Absorber and/or Hindered Nitroxide Radical on their Photostability
}

\author{
Reinaldo Ruggiero, ${ }^{* a}$ Antonio E.H. Machado, ${ }^{a}$ William Hoareau, ${ }^{b}$ Christian Gardrat, ${ }^{b}$ \\ Aziz Nourmamode, ${ }^{b}$ Stéphane Grelier $^{b}$ and Alain Castellan ${ }^{*, b}$ \\ ${ }^{a}$ Laboratório de Fotoquímica e Química de Lignocelulosicos, Universidade Federal de Uberlândia, CP 596, \\ 38400-100 Uberlândia-MG, Brazil \\ ${ }^{b}$ Laboratoire de Chimie des Substances Végétales, Université Bordeaux 1, F-33405 Talence, France
}

Fibras de bagaço de cana-de-açúcar não alvejadas (FBC) e alvejadas com peróxido de hidrogênio (FBC-AP) foram enxertadas com o absorvedor de UV hidroxifenilbenzotriazol (1) e/ou com um radical nitróxido do tipo piperidiniloxi (3). As fibras FBC-AP foram também acetiladas com anidrido acético. A fotossensibilidade dessas fibras à radiação UV foi avaliada comparativamente, empregando coordenadas Lab color, assim como pela monitoração dos seus espectros de reflectância difusa no UV-Visível. As fibras FBC mostraram-se fotoestáveis, enquanto que as FBC-AP apresentaram certa sensibilidade à radiação UV. A estabilidade das FBC deve-se à presença de unidades do composto fotoestável $p$-hidroxifenilpropano, proveniente dos fragmentos de lignina. As fibras FBC enxertadas e não-enxertadas apresentam comportamentos similares frente à radiação UV e Visível enquanto que as FBC-AP enxertadas são fotoestabilizadas pela presença de $\mathbf{2}$ ou 4, ou ambos. A acetilação das fibras FBC-AP induz a fotoestabilização, em adição a certo efeito de fotoalvejamento. O fotoalvejamento foi também apresentado por medidas de emissão de fluorescência. Como consequiência dessas observações, as fibras FBC devem ser consideradas como materiais lignocelulósicos com elevado potencial de aplicação em ambientes externos.

Unbleached (SCB) and peroxide bleached (PB-SCB) sugarcane bagasse fibers were grafted with hydroxyphenylbenzotriazole UV absorber (1) and/or hindered nitroxide radical of piperidinyloxy type (3). PB-SCB fibers were also acetylated with acetic anhydride. The photosensitivity of the various fibers to UV light was comparatively evaluated using Lab color coordinates and by monitoring their UV-Visible diffuse reflectance spectra. SCB fibers were found to be photostable whereas PB-SCB fibers presented some sensitivity to UV light. The stability of SCB fibers was attributed to the presence of photostable para-hydroxyphenylpropane units in SCB lignin. The grafted and non-grafted SCB fibers showed similar behaviors against UV-Visible light whereas grafted PB-SCB were photostabilized by the presence of $\mathbf{2}$ or $\mathbf{4}$ or both. Acetylation of PB-SCB fibers induced photostabilization in addition to some photobleaching effect. The photobleaching was also revealed by fluorescence emission studies. As a consequence of these observations, SCB fibers might be considered to have a high potential for lignocellulosic materials to be used outdoors.

Keywords: bagasse fibers, photodegradation, photoprotection

\section{Introduction}

Fibers obtained from biomass are cheap, non-toxic and easily recyclable. Their use contributes to environmental protection. ${ }^{1}$ Among them, sugarcane bagasse is a poorly valorized waste residue from sugar and alcohol industries.

*e-mail: reinaldo@ufu.br; a.castellan@1csv.u-bordeaux1.fr
It is usually burnt for energy supply. Valorization of this material includes pulps, ${ }^{2}$ thermoset composites, ${ }^{3}$ outdoor usages, ${ }^{4}$ cement strengtheners ${ }^{5}$ and materials for cleaning water from heavy metal contaminants. ${ }^{6}$ Another important research field involving this material is its bioconversion to produce protein rich animal aliment, enzymes, amino acids and pharmacological compounds. ${ }^{7}$ Lignocellulosic materials are sensitive to irradiation in the range from 
300 to $400 \mathrm{~nm}$ and up to $500 \mathrm{~nm}$ for some wood species. ${ }^{8-10}$ Color modification of lignocellulosic materials on UVVisible light exposure was mainly attributed to lignin. ${ }^{10}$ Abstraction of benzylic hydrogen by peroxides, followed by cleavage of $\beta-\mathrm{O}-4$ bonds, is the major lignin depolymerization pathway. ${ }^{11,12}$ Phenoxy radicals are key intermediates because they are further oxidized into colored chromophores ${ }^{13}$ such as ortho- and paraquinones. ${ }^{14,15}$ Recently, we have shown that dibenzodioxocin units of lignin are photoreactive, due to the cleavage of their $\alpha-\mathrm{O}-4$ and $\beta-0-4$ bonds, and contribute to the breakdown of the lignin polymer. ${ }^{16}$

It is possible to limit to some extent the photodiscoloration of peroxide bleached lignin-rich pulps, to use them for printing papers as substitute of bleached kraft pulps, by impregnating, coating or grafting with mixtures of UV-absorbers and radical scavengers (and/ or antioxidants). ${ }^{17-20}$ Coating is one of the most effective treatments to protect wood, ${ }^{21,22}$ whereas chemical modification of wood by esterification met some success. ${ }^{23,24}$ For clear woods, the combined action of hydroxybenzophenone or hydroxyphenylbenzotriazole UV absorbers and antioxidants such as hindered amine light stabilizers (HALS) or polyethylene glycols is quite efficient, ${ }^{25}$ especially when the additives are grafted at the wood surface. ${ }^{26}$ Titanium, zirconium, manganese, chromium, iron or copper derivatives confer some photoprotection to wood. ${ }^{27,28}$ Polyester binders containing benzotriazole and HALS or waterbased UVcured polyurethane-acrylate coating were also developed for the same goal. ${ }^{29,30}$

Our present research interest concerns ways to transform sugarcane bagasse fibers into useful materials, such as board and composites.31,32 For board materials in outdoor uses, their photostability might be questionable and the photochemical behavior of these fibers to UVVisible irradiation needs basic knowledge. Very recently, ${ }^{33}$ we have shown that acidolysis lignins of peroxide bleached and unbleached bagasse fibers present a high content in p-hydroxyphenylpropane units compared to hardwood and softwood. Both lignins are degraded by UV light, but among the photoreactive phenols, hydroxyphenyl units are the most resistant.

The present work describes an approach of the photodegradation by UV-Visible light of sugarcane bagasse fibers (hydrogen peroxide bleached or not) and some attempt to protect them by acetylation or grafting of a hydroxyphenylbenzotriazole ultraviolet absorber, $\mathbf{1}$, or a hindered nitroxide compound, 2,2,6,6-tetramethyl4-hydroxypiperidine-1-oxyl radical, $\mathbf{3}$, or a mixture of $\mathbf{1}$ and 3 (Scheme 1). The photocoloration of the fibers was estimated by measuring their color $\mathrm{L}^{*}, \mathrm{a}^{*}$ and $\mathrm{b}^{*}$ coordinates, their UV-Visible diffuse reflectance spectra versus irradiation time and for the acetylated fibers their fluorescence emission by comparison to non-acetylated fibers.

\section{Experimental}

\section{Fibers}

The sugarcane fibers were obtained from CIRAD, Réunion Island (France). They were extracted (soxhlet) with cyclohexane/ethanol (1/1, v/v) for $48 \mathrm{~h}$ and then with water for $24 \mathrm{~h}$. The fibers were dried in an aircirculated stove $\left(60{ }^{\circ} \mathrm{C}\right)$ until constant weight. The bleached fibers $(50 \mathrm{~g})$ were placed in a polypropylene bag and treated with a mixture of $\mathrm{Na}_{2} \mathrm{SiO}_{3}, 5 \mathrm{H}_{2} \mathrm{O}(3.15$ g); $\mathrm{MgSO}_{4}, 7 \mathrm{H}_{2} \mathrm{O}(0.25 \mathrm{~g})$; DTPA (0.125 g) and $\mathrm{NaOH}$ $(0.75 \mathrm{~g})$ in water $(280 \mathrm{~mL})$. Hydrogen peroxide $(35 \%$, $2.6 \mathrm{~mL}, 2 \%$ by reference to dry fibers) was added to the mixture and heated at $55^{\circ} \mathrm{C}$ for 2 hours. The fibers were filtered and washed with water. The bleaching procedure was repeated once. At the end, fibers were washed with dilute hydrochloric acid and water to bring the $\mathrm{pH}$ near 5 and finally dried in an air-circulated stove $\left(60{ }^{\circ} \mathrm{C}\right)$ until constant weight.

Alkaline hydrogen peroxide bleached fibers $(6.1 \mathrm{~g})$ were placed in a $500 \mathrm{~mL}$ flask with $12.5 \mathrm{~mL}$ of acetic anhydride, $12.5 \mathrm{~mL}$ of dried pyridine and $100 \mathrm{~mL}$ of dimethylformamide. The mixture was heated at $60{ }^{\circ} \mathrm{C}$ with magnetic stirring for 12 hours. The fibers were filtered, thoroughly washed with ethanol and acetone to remove the remaining chemicals and dried at room temperature for 12 hours and then over phosphorous pentoxide.

\section{Physical methods and ultraviolet irradiations}

The UV-Visible diffuse reflectance spectra were registered on a Perkin Elmer Lambda 18 spectrometer equipped with an integrating sphere (Labsphere, 150 mm). FTIR spectra were obtained with a Perkin Elmer Paragon 1000-PC spectrometer. Color measurements on fibers were performed using a L\&W Elrepho reflectometer according to ISO 2470 standard which gives the values of $\mathrm{L}^{*}, \mathrm{a}^{*}, \mathrm{~b}^{*}$ in the CIE-LAB system. The fluorescence spectra of the solid samples were measured with a Spex Fluorolog fluorimeter using a front face setup ensuring maximum fluorescence intensity with the minimum scattered light emission. The emission spectra were corrected for instrumental response of the emission 
monochromator-photomultiplier system. NMR spectra were recorded using a Bruker DPX400 spectrometer. For artificial light ageing, the fibers were placed in a Pyrex container, disposed on a rotational support to ensure uniform irradiation $\left(5\right.$ cycles $\left.\mathrm{min}^{-1}\right)$, surrounded by a Pyrex glass jacket with water circulation to dissipate the heat produced by two parallel medium-pressure mercury lamps (400 W). The Pyrex vessel eliminates wavelengths below $300 \mathrm{~nm}$, very detrimental for the cellulose fibers. With this setup, the temperature experienced by the fibers does not exceed $30{ }^{\circ} \mathrm{C}$. After each irradiation period, the fibers were pressed to form a pad for measuring color data and recording diffuse reflectance UV-Visible spectra.

\section{Synthesis of 1 and 3 derivatives}

The UV-absorber isocyanate, 2-benzotriazol-2-yl-4(isocyanato-ethyl)-6-tertiobutylphenol, 1 (Scheme 1) was synthesized according to a procedure already described..$^{26}$ The ${ }^{1} \mathrm{H}$ and ${ }^{13} \mathrm{C}$ NMR spectra of compound $\mathbf{1}$ confirm its structure. ${ }^{26}$

The synthesis of $\mathbf{3}$ (Scheme 1) needed the preparation of 2,2,6,6-tetramethyl-4-hydroxypiperidine-1-oxyl radical. ${ }^{34}$ Oxone $(36.6 \mathrm{~g}, 59.5 \mathrm{mmol})$ in water $(200 \mathrm{~mL})$ was added dropwise to a mixture of 2,2,6,6-tetramethylpiperidine-1,4-diol (Aldrich, $3.96 \mathrm{~g}, 25.2 \mathrm{mmol}$ ), acetone $(10 \mathrm{~mL})$ and phosphate buffer (Aldrich, $50 \mathrm{~mL})$. A potassium hydroxide solution (10\%) was added simultaneously to keep the $\mathrm{pH}$ at 7.5-8. After $2 \mathrm{~h}$ stirring at room temperature, the mixture was extracted with methylene chloride. After crystallization, an orange solid (1.48 g, 34\%) was obtained. mp $68-69{ }^{\circ} \mathrm{C}$ (methylene chloride).

1,6-Hexamethylenediisocyanate $(0.52 \mathrm{~g}, 3.1 \mathrm{mmol})$ in tetrahydrofuran $(25 \mathrm{~mL})$ at room temperature under nitrogen atmosphere was added slowly ( $3 \mathrm{~h})$ to a solution of freshly prepared 2,2,6,6-tetramethyl-4hydroxypiperidine-1-oxyl radical $(0.54 \mathrm{~g}, 3.1 \mathrm{mmol})$ in tetrahydrofuran $(20 \mathrm{~mL})$. After the addition, the mixture was refluxed for $1 \mathrm{~h}$. The solvent was evaporated and after column chromatography $\left(\mathrm{CH}_{2} \mathrm{Cl}_{2} /\right.$ petroleum ether, $8 / 2, v / v)$ of the residue, compound $\mathbf{3}$ was obtained (48\%, one spot in TLC). IR $(\mathrm{NaCl}) v_{\max }$ ' $\mathrm{cm}^{-1}$ : 3344, 2942, 2861, 2272, 1727, 1720, 1694, 1537, 1463, 1360 and 1238. ${ }^{13} \mathrm{C} \mathrm{NMR}\left(\mathrm{CDCl}_{3} 100 \mathrm{MHz}\right) \delta$ $22.5,28.4,28.5,32.8,33.4,43.6,46.1,61.3,123.4$ $(\mathrm{N}=\mathrm{C}=\mathrm{O}$ carbon $), 158.3(\mathrm{OC}(\mathrm{O}) \mathrm{NH}$ carbon $)$. The presence of a nitroxyl radical in the molecule did not allow detection of clean ${ }^{1} \mathrm{H}$ NMR signals. LSIMS (35 $\mathrm{keV}$, matrix: $m$-nitrobenzyl alcohol): $m / z, 340(\mathrm{M}+\mathrm{H})^{+}$
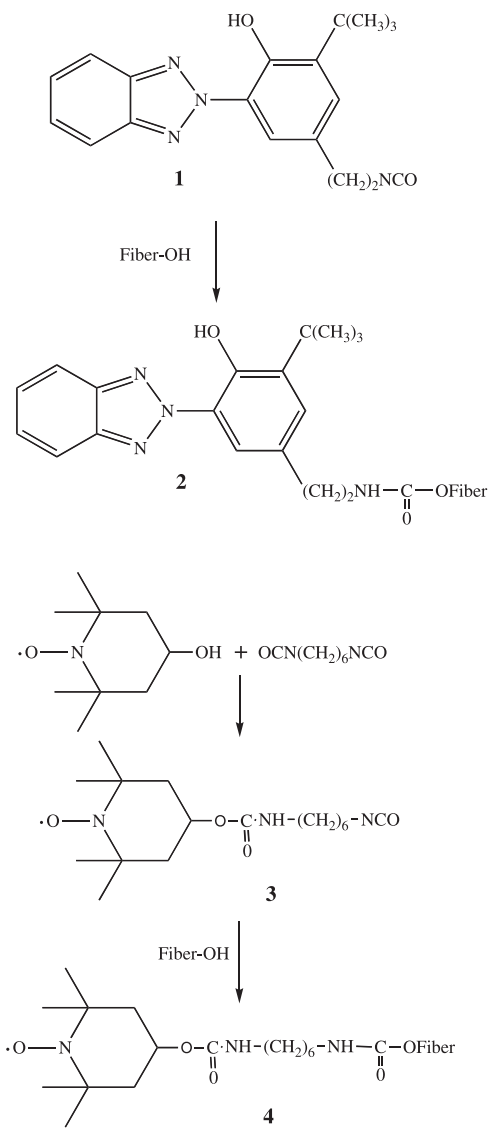

Scheme 1. Formulae of compounds $\mathbf{1}$ and $\mathbf{3}$ and their derivatives grafted on fibers (2 and $\mathbf{4})$.

\section{Grafting of $\mathbf{1}$ and $\mathbf{3}$ derivatives onto bagasse fibers}

Compound $1(60 \mathrm{mg})$ in acetone solution $(100 \mathrm{~mL})$ was added to dried sugarcane bagasse fibers $(6 \mathrm{~g}$ accurately weighted). After $30 \mathrm{~min}$ stirring, the solvent was evaporated and the grafting was achieved by heating the fibers for $1 \mathrm{~h}$ at $80^{\circ} \mathrm{C}$. The fibers were washed several times with acetone $(5 \times 50 \mathrm{~mL})$ and dried for $4 \mathrm{~h}$, at $80^{\circ} \mathrm{C}$. This procedure was shown to be appropriate to graft UV-absorber and HALS isocyanates onto lignocellulosic materials, ${ }^{26}$ despite no evidence of the grafting was obtained by FTIR or CP-MAS NMR spectroscopies. The grafting procedure was repeated to obtain at about $1 \%(\mathrm{~m} / \mathrm{m})$ grafting, 2. This value was estimated by measuring the weight gain of fibers before and after reaction; it corresponds to the amount of non-reacted $\mathbf{1}$, measured by UV absorption spectrometry.

Compound $3(120 \mathrm{mg})$ in acetone solution $(100 \mathrm{~mL})$ was added to dried sugarcane bagasse fibers ( $6 \mathrm{~g}$ accurately weighted). After $1 \mathrm{~h}$ stirring, the solvent was evaporated and the grafting was achieved by heating the fibers for $2 \mathrm{~h}$, at $80^{\circ} \mathrm{C}$. The fibers were washed several times with 
acetone $(5 \times 50 \mathrm{~mL})$ and dried for $4 \mathrm{~h}$, at $80{ }^{\circ} \mathrm{C}$. This procedure was duplicated to obtain at about $1 \%(\mathrm{~m} / \mathrm{m})$ grafting, 4. This value was estimated by measuring the weight gain of fibers before and after reaction; it corresponds to the weight of non-reacted $\mathbf{3}$.

The same experimental procedure was adopted to graft both 1 and $\mathbf{3}$ on fibers. For this purpose, a mixture of the two compounds was used, the residual 1 was titrated by UV absorption spectroscopy. The amounts of grafted $\mathbf{1}$ and 3 were estimated at about $0.5 \%$ for each compound.

\section{Results and Discussion}

\section{Bleaching action of hydrogen peroxide on fibers}

The action of $\mathrm{H}_{2} \mathrm{O}_{2}$ in alkaline medium on sugarcane fibers induced a visual bleaching effect; it is less efficient than for wood fibers due to the presence of cinnamic acids. ${ }^{35}$ This change is mainly due to the luminance of fibers, the $\mathrm{L} *$ value increasing drastically (SCB: 75; PB-SCB: 84), giving a brighter aspect to the bleached fibers. The green-red component coordinate $\mathrm{a}^{*}$ is almost not affected by the alkaline-peroxide treatment (SCB: 1.6; PB-SCB: 1.4) whereas the blueyellow coordinate $b^{*}$ increases after bleaching (SCB: 19.4; PB-SCB: 21.2), in accordance with the yellow aspect of the fibers.

\section{Photocoloration of fibers after grafting of UV-absorber and/or hindered nitroxide}

The choice of grafting UV-absorbers and hindered nitroxide isocyanates on fibers, as protecting agents, was made according to the good results observed on high-yield pulps and clear woods when hydroxyphenylbenzotriazole UV-absorber and HALS or HNOradical scavenger types were used. ${ }^{17,26,30}$ The grafting does not modify in a large extent the color coordinates of SCB fibers (Figure 1a), whereas those of PB-SCB are more affected, especially the luminance $\mathrm{L}^{*}$ when UV absorber is grafted (Figure 1b). It is likely that the bleaching changes the surface of the fibers and during the condensation of the isocyanate group, this surface is modified again, affecting the scattering of the fibers, which contributes to the luminance.

UV-Visible light emitted by the medium-pressure mercury lamps induces brightening ( $\mathrm{L}^{*}$ coordinate) of the SCB fibers (Figure 1a). This might be due to the general well-known photobleaching effect observed when colored woods are exposed to visible light. ${ }^{8}$ The presence of $\mathbf{2}$ or $\mathbf{4}$, alone or in combination, have no
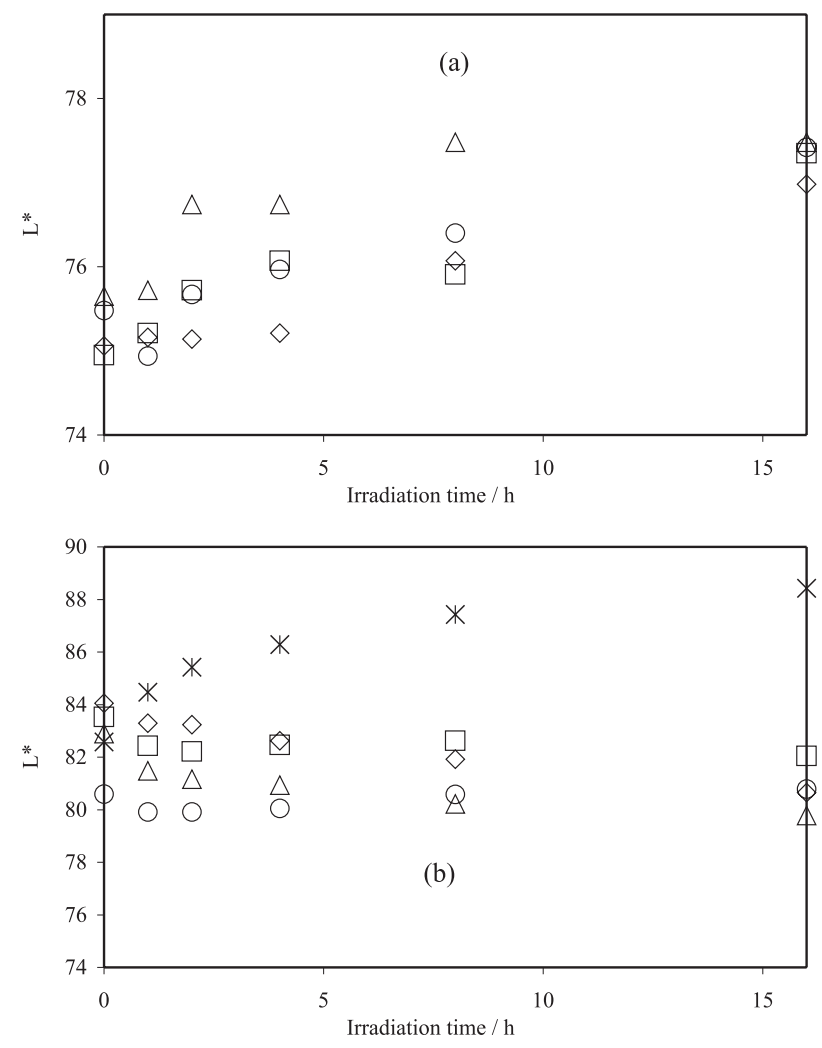

Figure 1. Evolution of luminance coordinate of fibers versus irradiation time, using light emitted by two medium-pressure mercury lamps (400 W) and filtered by a Pyrex glass to eliminate wavelengths below $300 \mathrm{~nm}$ (temperature at about $30{ }^{\circ} \mathrm{C}$ ). (a) $\diamond$ : untreated SCB; O: SCB with $2(\approx$ $1 \%$ basis weight); $\square$ : SCB with 4 ( $\approx 1 \%$ basis weight); $\triangle$ : SCB with 2 ( $\approx$ $0.5 \%$ basis weight) and 4 ( $\approx 0.5 \%$ basis weight). (b) $\diamond$ : untreated PB$\mathrm{SCB}$; $\bigcirc$ : PB-SCB with 2 ( $\approx 1 \%$ basis weight); $\square$ : PB-SCB with 4 ( $\approx 1 \%$ basis weight); $\triangle$ : PB-SCB with $2(\approx 0.5 \%$ basis weight $)$ and $4(\approx 0.5 \%$ basis weight); $*$ : acetylated-PB-SCB.

great influence on this phenomenon. Similar effects were observed for oak wood grafted with UV-absorbers and HALS. ${ }^{26}$ By contrast, continuous decrease of luminance coordinate is observed for PB-SCB fibers under irradiation (Figure 1b). Grafting the bleached fibers with hindered nitroxide $\mathbf{4}$ stabilizes the luminance at a high level, whereas the presence of $\mathbf{2}$ lowers it, but keeps its value quite constant under irradiation. Half concentration of $\mathbf{2}$ and $\mathbf{4}$ on fibers (total grafting at about $1 \%$ ) does not bring protection by contrast to peroxide bleached high-yield pulps. ${ }^{36}$ This is probably related to the antioxidant mobility (important in pulps and reduced in grafted $\mathrm{PB}-\mathrm{SCB}$ fibers), because it has been shown that hindered nitroxides are acting as protectors of $2 .{ }^{37}$ This mechanism cannot operate completely when the local concentration in $\mathbf{4}$ is too low.

The green-red coordinate $\mathrm{a}^{*}$ of SCB fibers does not change so much when fibers are exposed to UV-Visible 
light. Grafting hindered nitroxide $\mathbf{4}$ does not affect this behavior (Figure 2a). By contrast, fibers grafted with $\mathbf{2}$ show a slight increase of $a^{*}$ in the first hour of irradiation, and remains constant after longer irradiation times (Figure 2a). This sensitivity might be ascribed to a non-planar conformation of the hydroxyphenylbenzotriazole molecule, which precludes proton transfer between the phenol and a triazole nitrogen, involved in the protecting effect. ${ }^{17}$ The usual sensitivity of peroxide bleached lignocellulosic materials to UV light ${ }^{9}$ is observed for PB-SCB fibers (Figure 2b). The formation of red ortho-quinones by demethoxylation of guaiacyl and syringyl phenols of lignin are likely responsible for the $a^{*}$ increase under irradiation. ${ }^{9}$ The presence of $\mathbf{4}$ on peroxide bleached fibers provides them with an important photostability. This observation is comparable to the general action of $\mathbf{4}$ on lignin-rich pulps. ${ }^{17}$ The increase of $a^{*}$ coordinate noted for SCB fibers grafted with $\mathbf{2}$ is also observed for PB-SCB fibers. The presence of both $\mathbf{2}$ and $\mathbf{4}$ grafted on PB-SCB fibers induces $\mathrm{a}^{*}$ constancy at a value higher than for $\mathrm{SCB}$ fibers, when they are irradiated.

The blue-yellow coordinate $b^{*}$ of SCB and PB-SCB is not very sensitive to photoirradiation of fibers (curves not shown). However, a slight increase is noted for SCB
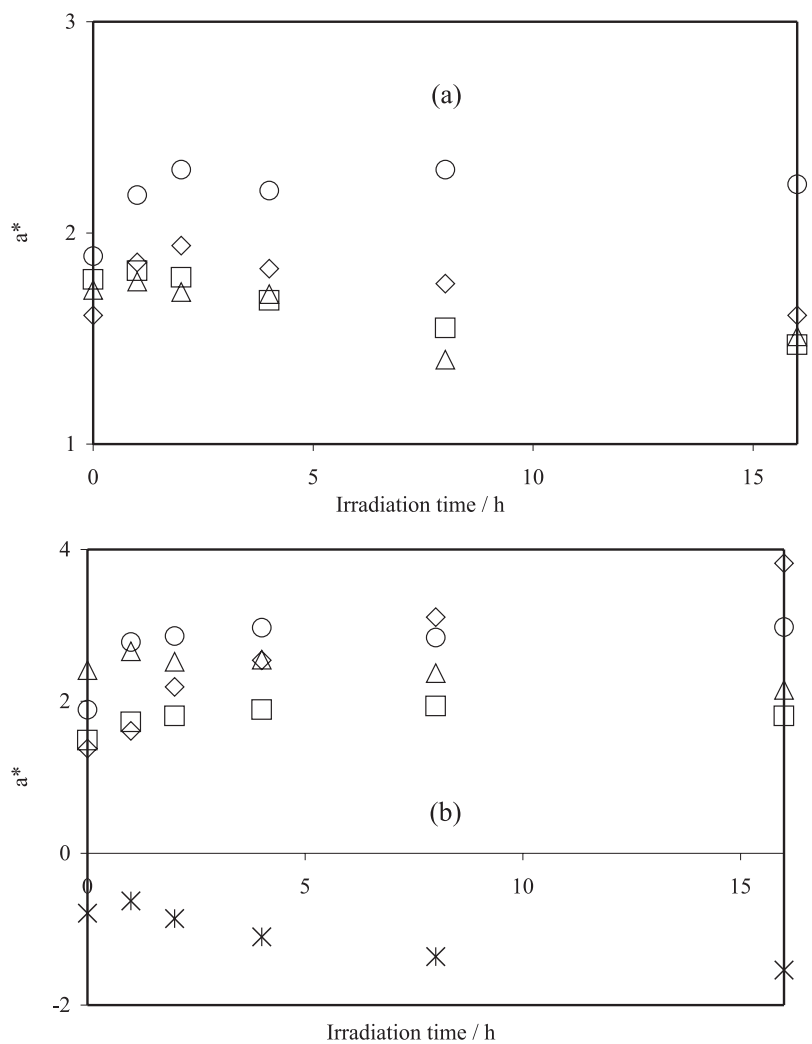

Figure 2. Evolution of green-red coordinate a* of SCB fibers versus irradiation time (see Figure 1). $\left(b^{*}{ }_{t=0}: 19.4 ; b_{t=16 h}^{*}: 20.7\right)$ which might be due to the formation of yellow chromophores such as paraquinones. ${ }^{15}$ Grafting $\mathbf{1}$ or $\mathbf{3}$ or both on SCB fibers, leads to a decrease of $b^{*}$ value in the first half hour irradiation; $b *$ remains practically constant after this time period (curve not shown). It seems that photogeneration of para-quinones from their corresponding hydroquinones (absorbing in UV region) ${ }^{38}$ is diminished by the presence of UV absorber or hindered nitroxide.

Diffuse reflectance spectra (expressed in pseudo absorbance units, $\log (1 / \mathrm{R}))$ of all fibers, grafted or not, have been recorded. They confirm the Lab data. As an example in Figure 3, the curves of SCB and PBSCB fibers before and after 16 hours irradiation time are presented. The similarity between irradiated and non-irradiated SCB fibers (Figure 3a) underlines the exceptional photostability of these natural fibers. The peroxide bleaching induces light sensitivity, a new absorption band being formed between 400 and 650 $\mathrm{nm}$, in accordance with the decrease of $\mathrm{L}^{*}$ value during irradiation (Figure 3b). Similar results have been observed for lignin-rich softwood pulps. ${ }^{9}$ The protective role of $\mathbf{4}$ is clearly seen in Figure $4 \mathrm{c}$, where the irradiated and non-irradiated grafted PB-SCB fibers display similar diffuse reflectance spectra. The same conclusions can be drawn with $\mathbf{2}$ or both $\mathbf{2}$ and $\mathbf{4}$ grafted fibers (spectra not shown).

We have shown recently ${ }^{33}$ that para-hydroxyphenylpropane units $(\mathrm{H})$ in acidolysis sugarcane bagasse lignin are much more photostable than the guaiacyl $(\mathrm{G})$ and syringyl (S) ones. The presence of large amounts of $\mathrm{H}$ component versus $\mathrm{G}$ and $\mathrm{S}$ in $\mathrm{SCB}$ fibers ${ }^{32}$ might partially explain the remarkable photostability of unbleached sugarcane fibers. The bleaching by hydrogen peroxide removes quinones and cinnamaldehydes, but introduces peroxy and hydroperoxy compounds in the lignin polymer, which are very sensitive to UV-Visible light. Therefore the needs of protective agents such as hindered nitroxide and UVabsorber appear necessary for bleached fibers but unnecessary for natural fibers.

\section{Photocoloration of peroxide bleached fibers after acetylation}

Another way to photostabilize bleached mechanical pulp involves acetylation employing acetic anhydride. ${ }^{39}$ Although acetylation concerns polysaccharides and lignin, the photostabilization effects are generally attributed to acetylation of lignin, with phenolics being preferentially acetylated over aliphatic hydroxyl 

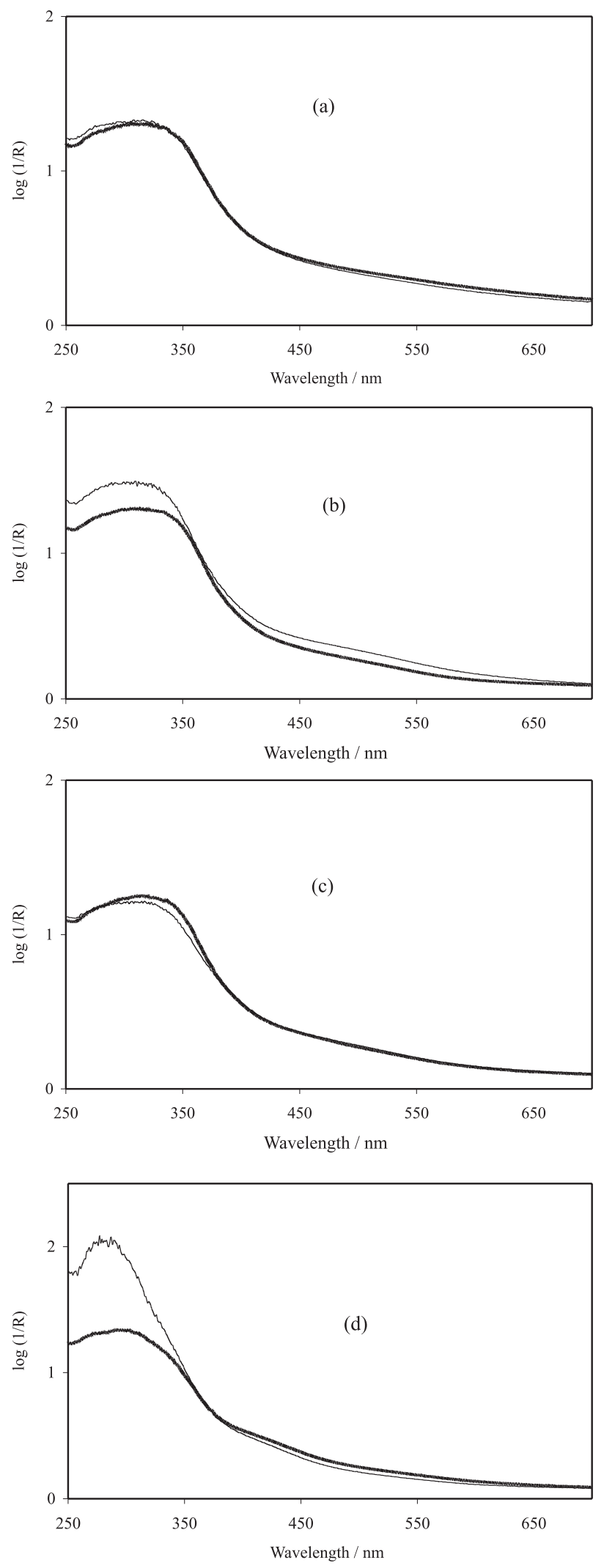

Figure 3. Diffuse reflectance spectra of fibers. (-): non-irradiated fibers; (—): fibers irradiated 16 hrs (see experimental part). (a) SCB fibers; (b) PB-SCB fibers; (c) PB-SCB with 4 ( $\approx 1 \%$ basis weight); (d) acetylated-PB-SCB fibers. groups. ${ }^{39}$ It is known that free phenolic groups in lignin play a key role in the photochemistry of lignocellulosic fibers ${ }^{25}$ however, Heitner ${ }^{40}$ showed that acetylation decreases the extent of photodegradation by hindering the cleavage of $\beta$-0-aryl ether groups and consequently the production of phenoxy radicals and lignin chromophores. The conversion of ortho-quinones by Thiel-Winter reaction to their triacetate derivatives is also beneficial to reduce the photoyellowing of the fibers. $^{39}$

We have used the acetylation procedure to improve the photostability of the bleached fibers, the unbleached ones being photostable enough (vide infra). In addition to UV-Visible diffuse reflectance spectroscopy and color measurements, fluorescence emission versus irradiation time was measured for acetylated and nonacetylated fibers. We have shown ${ }^{33}$ on lignin, extracted from PB-SCB by soft acidolysis, that fluorescence reveals the photodegradation process: e.g. orthoquinone formation in the beginning of irradiation, followed by photochemical breakdown of enone structural elements, which allows the fluorescence of aromatic chromophores of lignin to be seen at short wavelengths.

The FTIR spectra of PB-SCB fibers in $\mathrm{KBr}$ pellets (Figure 4) show an intense band at $1750 \mathrm{~cm}^{-1}$, which is characteristic of the carbonyl group in acetylated fibers. The presence of an intense band at $3427 \mathrm{~cm}^{-1}\left(\mathrm{v}_{\mathrm{OH}}\right)$, even after acetylation, is due to non-acetylated aliphatic hydroxyl groups and carboxylic acids, whereas phenolics are usually esterified. ${ }^{39}$ The other bands in the spectra are typical of lignocellulosic fibers. ${ }^{10}$

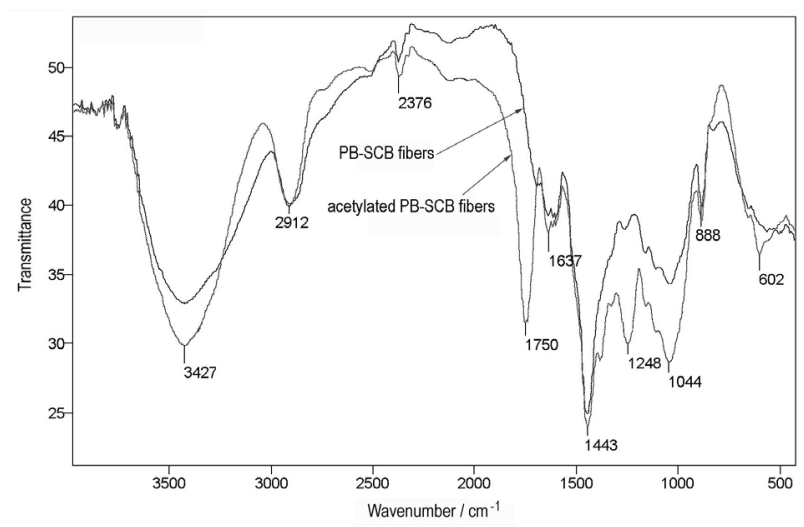

Figure 4. FTIR spectra of PB-SCB fibers and acetylated-PB-SCB fibers dispersed in $\mathrm{KBr}$ pellets (1\% weight).

The diffuse reflectance spectra of acetylated fibers before and after 16 hours irradiation (Figure 3d) indicate an increase of pseudo-absorbance in the UV region and a shift from $300 \mathrm{~nm}$ to $280 \mathrm{~nm}$. This effect is not observed on the non-acetylated fibers. An isomerization 
mechanism $(E / Z)$ involving the double bond of cinnamic acids, located as pendent groups, might compete on acetylated material, because other degradative pathways are reduced by acetylation. As observed on other acetylated lignocellulosic materials, a photobleaching effect is detected in the visible region due to the photolysis of quinonoid structures. ${ }^{39,40}$

The color data confirms the photobleaching effect, the luminance increases from 82.6 to 88.4 (Figure 1b), whereas the green-red color parameter $a^{*}$ (Figure $2 b$ ) is negative after acetylation, due to the reactivity of colored quinones. The irradiation induces a slight increase followed by a decrease, of the $a^{*}$ coordinate, in accordance to the formation and photolysis of ortho-quinones (vide infra). The $b^{*}$ parameter measures the color variation from blue to yellow. Acetylation increases the $b^{*}$ value in accordance with the deeper yellowish aspect of the fibers after reaction. For this color parameter, a decrease is observed upon irradiation (curve not shown), in accordance with the photodegradation of quinones, the para-quinones being more involved in the yellow part of the spectrum.

Fluorescence emission studies on non acetylated fibers (Figure 5a) show a slight intensity increase at the beginning of irradiation and then a continuous decrease of the intensity is measured; a more structured spectrum is observed with two peaks at 430 and 470 $\mathrm{nm}$. This effect is the opposite as it was observed for acidolysis lignin in solution (vide infra). The photophysical and photochemical processes are not the same in the solid state and in solution, due to different lifetimes of the formed radical species, for example phenoxy radicals, key intermediates in the photodegradation process. Formation of complex enones in the solid state, that quench the fluorescence of aromatic structures, such as biphenyls and stilbenes, might account for the observed behavior of the PB-SCB fibers. For the acetylated fibers, the fluorescence emission displays a large band between 400 and $600 \mathrm{~nm}$, which increases at the beginning of the irradiation. After 16 hours irradiation, a slight intensity decrease is detected; a better definition of the spectrum is seen, with a well defined peak at $480 \mathrm{~nm}$ and a shoulder at $438 \mathrm{~nm}$. For acetylated fibers, the acetylation of phenols limits their involvement at the beginning of the process. So, the bleaching action of light on colored chromophores might occur, as it was observed by UV-Visible diffuse reflectance spectrometry. After 16 hours irradiation time, the oxidative process is occurring on phenols, formed by cleavage of $\beta$-0-aryl ether groups, producing enones that quench the fluorescence of the aromatic structural elements.
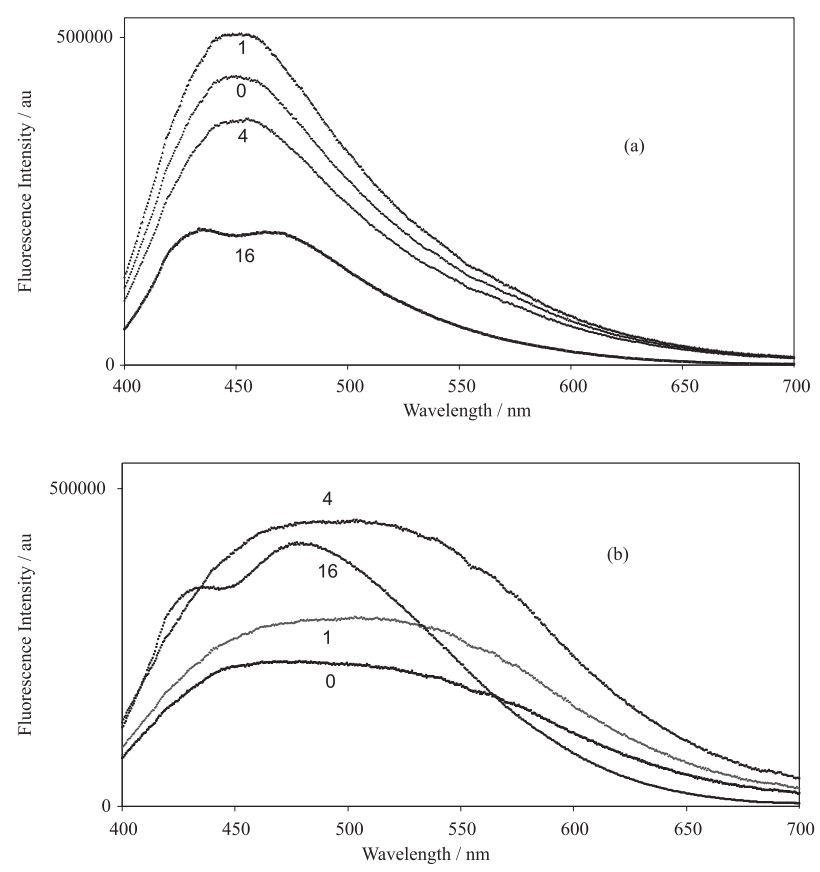

Figure 5. Emission fluorescence spectra of fibers irradiated for various periods of time: $0,1,4$ and 16 hours. (a): PB-SCB fibers; (b): acetylatedPB-SCB fibers $\left(\lambda_{\text {excitation }}: 373 \mathrm{~nm}, \mathrm{f}_{\text {excitation }}=\mathrm{f}_{\text {emission }}=2 \mathrm{~nm}\right.$, room temperature, fluorescence recorded in surface mode).

\section{Conclusions}

Sugarcane bagasse fibers are close to hardwood fibers when considering their chemical composition and their lignin and carbohydrate contents. Using them as substitute of wood fibers in many applications might be of great interest. The present study has established that they display a high color photostability without using protective treatments such as acetylation or coating with UV absorbers and/or hindered nitroxides, as needed for clear wood fibers. Their high content in $p$-hydroxyphenylpropane units compared to hardwood and softwood induces a low photosensitivity to light. The use of acetylation or UV-absorber and hindered nitroxide stabilizers appears only necessary when clear material is needed, which involves a peroxide bleaching stage. The high photostability of sugarcane bagasse fibers appears to be an important factor to promote their use to prepare materials susceptible to be exposed to light.

\section{Acknowledgments}

The authors are grateful to CAPES/COFECUB (Project 422/03) for traveling missions between Brazil and France. W.H. is very grateful to Conseil Régional de la Réunion (France) and to Fonds Social Européen (FSE) for a doctoral 
grant. R.R. thanks CAPES for financial support. A.E.H.M. is grateful to CNPq (National Council of Scientific and Technologic Development) for attribution of a research productivity fellowship.

\section{References}

1. Chen, H. L.; Porter, R. S.; J. Appl. Polym. Sci. 1994, 54, 1781.

2. Mohta, D.; Upadhyaya, J. S.; Kapoor, S. K.; Ray, A. K.; Roy, D. N.; Tappi J. 1998, 81 (6), 184.

3. Paiva, J. M. F.; Frollini, E. In Natural Polymers and Agrofibers Based Composites; Frollini, E.; Leão, A. L.; Mattoso, L. H. C., eds.; Embrapa Instrumentação Agropecuária: USP São Carlos, Brazil, 2000, p. 229.

4. Iñiguez-Covarrubias, G.; Lange, S. E; Rowell, R. M.; Bioresour. Technol. 2001, 77, 25.

5. Martinez, C. M. F.; Frollini, E.; Campana Filho, S. P.; Polímeros: Ciência e Tecnologia 1997, 7, 48.

6. Peternele, W. S.; Winkler-Hechenleitner, A. A.; Gómez Pineda, E. A.; Bioresour. Technol. 1999, 68, 95.

7. Pandey, A.; Soccol, C. R.; Nigam, P.; Soccol, V. T.; Bioresour. Technol. 2000, 74, 69.

8. Déglise, X.; Merlin, A.; L'Actualité Chimique 1994, 7 (suppl.), 156.

9. Heitner, C. In Photochemistry of Lignocellulosic Materials; Heitner, C.; Scaiano J. C., eds.; ACS Symposium Series: Washington DC, 1993, 531, p. 2.

10. Hon, D. N. S. In Wood and Cellulosic Chemistry; Hon, D. N. S.; Shiraishi, N., eds.; Marcel Dekker: New York-Basel, 1991, p. 525 .

11. Scaiano, J. C.; Netto-Ferreira, J. C.; Wintgens, V.; Photochem. Photobiol. A: Chem. 1991, 59, 265.

12. Palm, W. U.; Dreeskamp, H.; Bouas-Laurent, H.; Castellan, A.; Ber. Bunsenges. Phys. Chem. 1992, 96, 50

13. Leary, G.; Nature (London) 1968, 217, 672.

14. Argyropoulos, D. S.; Heitner, C.; Schmidt, J. A.; Res. Chem. Intermed. 1995, 21, 263.

15. Agarwal, U. P.; J. Wood Chem. Technol. 1998, 18, 381.

16. Gardrat, C.; Ruggiero, R.; Hoareau, W.; Nourmamode, A.; Grelier, S.; Siegmund, B.; Castellan, A.; J. Photochem. Photobiol. A: Chem. 2004, 167, 111.

17. McGarry, P.; Heitner, C.; Schmidt, J.; Seltzer, R.; Cunkle, G.; Wolf, J.-P.; J. Pulp Pap. Sci. 2000, 26, 59.

18. Petit-Conil, M.; De Choudens, C.; Castellan, A.; Grelier, S.; Davidson, R. S.; J. Pulp Pap. Sci. 1998, 24, 167
19. Ragauskas, A. J.; Allison, L.; Lucia, L. A.; Li, C.; Solutions/ Tappi J. 2001, 84 (11), 1.

20. Hu, T. Q.; Osmond, D. A.; Schmidt, J. A.; Polym. Degrad. Stabil. 2004, 83, 547 .

21. Feist, W. C.; For. Prod. J. 1988, 38, 22.

22. Podgorski, L.; Merlin, A.; Saiter, J. M.; J. Thermal Anal. 1994, 41,1319 .

23. Imamura, Y.; Wood Res. 1993, 79, 54.

24. Rowell, R. M.; Lichtenberg, R. S.; Larsson, P.; Wood Fiber Sci. 1993, 25, 359.

25. Castellan, A.; Nourmamode, A.; Grelier, S.; Fornier de Violet, P.; Cell. Chem. Technol. 1996, 30, 431.

26. Grelier, S.; Castellan, A.; Desrousseaux, S.; Nourmamode, A.; Podgorski, L.; Holzforschung 1997, 51, 511.

27. Allen, N. S.; Edge, M.; Ortega, A; Liauw, C. M.; Stratton, J.; McIntyre, R. B.; Polym. Degrad. Stabil. 2002, 78, 467.

28. Schmalzl, K. J.; Evans, P. D.; Polym. Degrad. Stabil. 2003, 82, 409.

29. Decker, C.; Masson, F.; Schwalm, R.; Polym. Degrad. Stabil. 2004, 83, 309.

30. Sundell, P; Sundholm, F.; J. Appl. Polym. Sci. 2004, 92, 1413.

31. Trindade, W. G.; Hoareau, W.; Razera, I. A. T.; Ruggiero, R.; Frollini, E.; Castellan, A.; Macromol. Mater. Eng. 2004, 289, 728.

32. Hoareau, W.; Trindade, W. G.; Siegmund, B.; Castellan, A.; Frollini, E.; Polym. Degrad. Stabil. 2004, 86, 567.

33. Ruggiero, R.; Machado A. E. H.; Gardrat, C.; Hoareau, W.; Grelier, S.; Siegmund, B.; Castellan, A.; J. Photochem. Photobiol. A: Chem. 2005, 173, 150 .

34. Murray, R. W.; Jeyaraman, R.; J. Org. Chem. 1985, 50, 2847.

35. Pan, G. X.; Thomson, C. I.; Leary, G. J.; Holzforschung 2003, $57,282$.

36. Fang, G. G.; Castellan, A.; Shen Z. B.; Chemistry Industry Forest Products 2000, 20, 33.

37. Beaton, C. R.; Argyropoulos, D. S.; Photochem. Photobiol. 2001, 73, 605 .

38. Castellan, A.; Colombo, N.; Nourmamode, A.; Zhu, J. H.; Lachenal, D.; Davidson, R. S.; Dunn, L.; J. Wood Chem. Technol. 1990, 10, 461 .

39. Pu, Y.; Anderson, S.; Lucia, L.; Ragauskas, A. J.; J. Photochem. Photobiol. A: Chem. 2004, 163, 215.

40. Heitner, C.; St John Manley, R.; Ahvazi, B.; Wang, J.; J. Pulp Pap. Sci. 2001, 27, 325.
Received: December 6, 2005

Published on the web: May 26, 2006 